\title{
REFERENCE VALUES FOR HEMATOLOGICAL AND SERUM BIOCHEMICAL CONSTITUENTS IN LATE PREGNANT BUFFALOES
}

\author{
M.R. ABD ELLAH*, MAHA I. HAMED*, D.R. IBRAHIM ${ }^{* *}$ and H.Z. RATEB ${ }^{* * * *}$ \\ * Department of Animal Medicine, Faculty of Veterinary Medicine, Assiut University, Egypt. \\ ** Department of Theriogenology, Faculty of Veterinary Medicine, Assiut University, Egypt. \\ ${ }^{* * * *}$ Veterinary Teaching Hospital, Faculty of Veterinary Medicine, Assiut University 71526, Assiut, Egypt.
}

\section{ABSTRACT}

Received at: $26 / 12 / 2012$

\section{Accepted: 21/1/2013}

Reference values for buffaloes especially those at late pregnancy are not yet established. The aim of this study was to establish serum biochemical and hematological reference intervals for water buffaloes (Bubalus bubalis) during the late pregnancy. A total number of 125 clinically healthy late pregnant (7.0-10.5 months) buffaloes (3-8 years old) were included in the study. The inclusion of animals in the study was based on numbers of basic selection criteria. Animals were examined at buffaloes' farms that belong to Assiut Governorate at the mid of Egypt. Three types of samples were collected; serum samples for biochemical analysis, whole blood samples for hematological analysis and fecal samples for parasitological examination. A total of 55 blood analytes were measured during this study. The $95 \%$ reference intervals for each serum biochemical and hematological constituents were calculated by removing the upper and lower $2.5 \%$ of the interval to give the 2.5 and 97.5 percentiles. The results revealed that serum biochemical and hematological constituents in late pregnant buffaloes showed some differences when compared with previously published data. In conclusion, the established reference values will be a useful guide for interpreting serum biochemical and hematologic data in late pregnant buffaloes, especially those live under the Egyptian environment.

Keywords: Serum, Hematology, buffalo, pregnant, reference values

\section{INTRODUCTION}

The buffalo (Bubalus bubalis) originally Asian animals and distributed mainly in tropical and subtropical Asia. The buffaloes are used for drought power and are found in countries like the Indian subcontinent and the Mediterranean countries (Cockril, 1980). The water buffalo can surpass the cattle genus Bos in its ability to adapt to the hot climates and swampy lands (Webster and Wilson, 1980); therefore, water buffaloes have special importance in milk and meat production in the valley of the River Nile in Egypt (GOVS, 2005).

Both clinical examination and various laboratory diagnostic tests are required for diagnosis of diseases. The major part of the laboratory diagnostic tests is the measurement of serum biochemical and hematological constituents that are used to determine general health status, diagnose diseases and physiological alterations (Theodossi et al., 1981;
Klinkhoff et al., 1988; Bailey et al., 1989 and Pattinson and Theron, 1989).

Textbook reference values reported by European or United States Veterinary Laboratories are often based on animals living under good husbandry conditions in temperate climates. However, those reference sample groups may differ from those of the developing countries. Differences may be attributed to the environmental temperature, the type and quantity of the ration and the management system. Published data propose erratic normal values that are often obtained from a relatively small number of animals, which kept under different nutritional and climatic conditions, it makes difficult to depend on such published data to interpret results for buffaloes live in Egypt. Reference values are not yet established for the water buffaloes (Bubalus bubalis). Consequently, the aim of the present study is to establish reference values for hematological and serum biochemical constituents in late pregnant buffaloes. 


\section{MATERIALS and METHODS}

\begin{abstract}
Animals
Buffaloes (3-8 years old), at the late pregnancy (7.010.5 months) were examined at buffalo farms (Land of Kheir buffaloes farm, at Abnoub city, Valley of Sheeh buffaloes farm at El-badary city and Bani Sanad buffaloes farm at El-hawatka), all together belonging to Assiut Governorate, Egypt. The study was carried out during the period from August 2011 till June 2012
\end{abstract}

Careful clinical examinations were carried out Pregnancy diagnosis was carried out by the ordinary methods. Only animals that met the basic selection criteria (Table 1) were included in the study. Pregnant buffaloes were kept together under open half shelter system. Ration received by buffaloes during the study were mixture of silage, hay, roughages, concentrates, and Egyptian clover (Trifolium alexandrinum). Water was supplied ad libitum.

A total number of 158 late pregnant buffaloes were examined. Out of them, 33 buffaloes did not meet the selection criteria described in Table 1, which were excluded from the study. The remained 125 animals were fit with the basic selection criteria and included in the study.

The ear tag number of the individual animal in the farm was recorded in examination sheet. Another serial number was assigned for each individual animal. Tubes used for collection of blood and cups used for fecal samples were assigned the same serial numbers that was recorded on the examination sheets.

\section{Samples}

Two blood samples were collected from the jugular vein into vacutainer tubes from all buffaloes; the first blood sample was collected in plain vacutainer tube $(10 \mathrm{ml}$ plain vacuum tubes, Biomedica Alex Co., Egypt) and used for obtaining serum. The second blood sample was collected in vacutainer tubes (Becton Dickinson vacutainer) containing EDTA and used for complete blood picture. Fecal samples were collected from the rectum of all animals in clean and dry cups. Samples were transported in ice tank directly after collection to the research laboratory (Department of Animal Medicine, Faculty of Veterinary Medicine, Assiut University, Egypt) within 1- $2 \mathrm{hrs}$ from collection of samples.

Samples were prepared (blood serum) or analyzed (whole blood and fecal samples) directly after receiving them by the research laboratory. Blood samples in plain tubes were centrifuged at $3000 \mathrm{rpm}$ for 15 minutes, serum was collected according to standard methods of hematology (Coles, 1986), and then was divided into 4 equal parts in eppendorf tubes, stored at $-20^{\circ} \mathrm{C}$, and were used for measuring serum biochemical constituents. Samples showing hemolysis were excluded from the study. Serum samples kept in deep freeze were analyzed within a maximum period of two weeks.

\section{Biochemical analysis}

\section{Serum biochemical analytes}

Serum biochemical parameters were measured using UV visible/spectrophotometer (Optizen 3220 UV, Mecasys Co. Ltd, Korea), reagents kits were supplied with the purchased commercial kits, different methods used for analysis of different serum biochemical variables were summarized in Table 2 . Biochemical analysis included measurements of serum total proteins, albumin, globulins, total cholesterol, triglycerides, high density lipoprotein (HDL-C), low density lipoprotein (LDL-C), very low density lipoprotein (VLDL-C), calcium, magnesium, chloride, phosphorus, iron, total iron binding capacity (TIBC), unsaturated iron binding capacity (UIBC), sodium, potassium, zinc, copper, aspartate aminotransferase (AST), alanine aminotransferase (ALT), gamma glutamyl transferase (GGT), lactate dehydrogenase (LDH), alkaline phosphatase (ALP), creatine phosphokinase (CK), blood urea nitrogen (BUN), creatinine, total bilirubin, direct bilirubin and indirect bilirubin levels.

\section{Serum protein electrophoresis}

Serum protein electrophoresis was carried out by using cellulose acetate electrophoresis kit (BiotecFischer GmbH, Germany) and by Electrophoresis Set (Filipo, Biotec-Fischer GmbH, Germany).

\section{Hematological analysis Blood film}

Air dried smear of fresh blood was prepared directly after collection, fixed and stained with Giemsa stain (Coles, 1986), and then examined for blood parasites and for differential leucocytes counts. Manual differential leucocytes counts were performed to calculate the relative and absolute counts for individual granulocytes (Neutrophils, band cells, eosinophils and basophils), this because, Medonic electronic blood cells counter produced one relative and absolute counts for all granulocytes.

\section{Hematological examination}

Hematological examination was performed directly after the samples being received by the research laboratory and within 1-2hrs from collection of blood and by using Medonic Veterinary Hematology analyzer (Medonic CA 620, Sweeden). The measured hematological analytes were total red blood cells count (T.RBCs), hemoglobin concentration (HGB), red blood cells distribution width (RDW), red blood 
cells distribution width absolute (RDWa), hematocrit (HCT), main corpuscular volume (MCV), mean corpuscular hemoglobin $(\mathrm{MCH})$, mean corpuscular hemoglobin concentration (MCHC), platelets count (PLT), mean platelets volume (MPV), platelets distribution width (PDW), large platelets concentration ratio (LPCR), plateletcrit (PCT), total white blood cells count (T.WBCs), and count and percentage of lymphocytes, neutrophils, band cells, eosinophils, monocytes, basophils.

\section{Parasitological analysis}

Parasitological analyses of fecal samples were done on the same day of collection using sedimentation and floatation techniques according to Soulsby (1982). Animals that harbored parasites were excluded from the study. The parasitological findings were reported to the farm to treat animals and to take recommended control measures.

\section{Data Analysis}

Data analysis was carried out according to approved recommendations of International Federation of Clinical Chemistry on the theory of reference values (Solberg, 1987). Statistical analysis was performed using Reference Value advisor version 2.1 (Geffré et al., 2011). Reference intervals were determined using the non-parametric method. Outliers were determined using Dixon-Reed's and Tukey's tests (Reed et al., 1971). Data were tested for normal distribution according to Anderson and Darling (1954). The 95\% reference intervals were calculated by removing the upper and lower $2.5 \%$ of the range for each serum biochemical and hematological constituents to give the 2.5 and 97.5 percentiles.

\section{RESULTS}

Results of statistical analysis for different biochemical and hematological analytes were arranged in Tables 3 , 4, 5, 6 and 7, and included mean values, standard deviation (SD) and reference intervals. Serum protein electrophoresis was shown in Fig. 1.

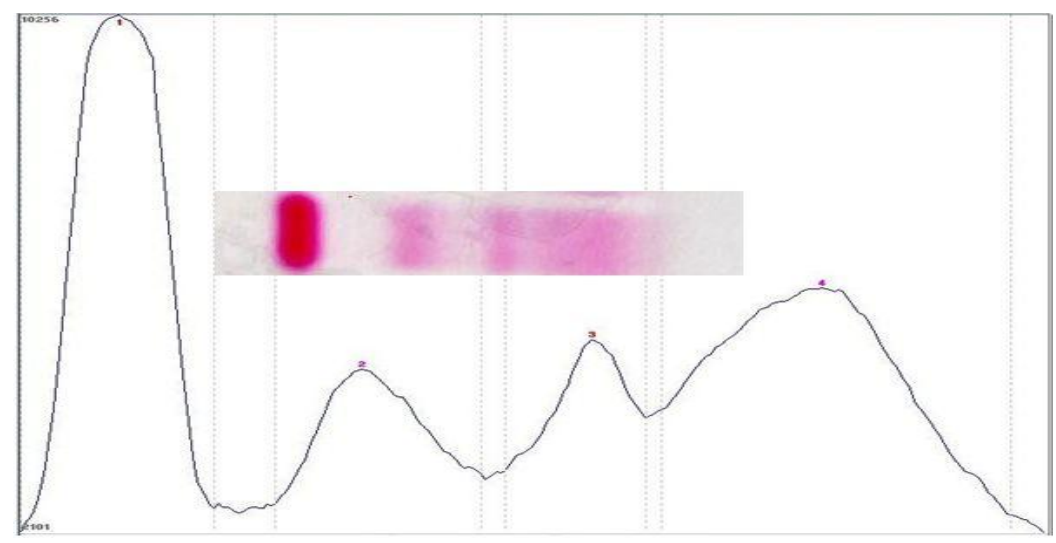

Fig. 1: Serum protein electrophoresis in late pregnant buffaloes

Table 1: Basic selection criteria for buffaloes

Clinically healthy buffaloes

None lactating

During late pregnancy (7.0-10.5 month)

Good body condition score

General attitude: alert

No loss of skin elasticity

Normal mucous membrane: pink

No diarrhea in previous 7 days

No urogenital abnormalities in previous 7 days

No muscular abnormalities in previous 7 days

No medication in previous 7 days

Absence of skin lesions or alopecia.

Absence of intestinal and blood parasites. 
$\underline{\text { Assiut Vet. Med. J. Vol. } 59 \text { No. } 136 \text { January } 2013}$

Table 2: Method used to measure serum biochemical variables in lactating buffaloes

\begin{tabular}{|c|c|c|}
\hline Analytes & Method & Source of Commercial kits \\
\hline Total proteins & Biuret colorimetric method & \multirow{10}{*}{ Spinreact, GIRONA, Spain } \\
\hline Albumin & Bromcresol green colorimetric method & \\
\hline Total cholesterol & CHOD-POD. Enzymatic colorimetric & \\
\hline Triglyceride & GPO-POD. Enzymatic colorimetric & \\
\hline High density lipoprotein & HDL, precipitating method & \\
\hline Low density lipoprotein & $\begin{array}{l}\text { LDL, Enzymatic colorimetric. Liquid } \\
\text { method }\end{array}$ & \\
\hline Glucose & $\begin{array}{l}\text { Glucose Oxidase-peroxidase enzymatic } \\
\text { colorimetric method }\end{array}$ & \\
\hline Calcium & o-Cresolphtalein. Colorimetric & \\
\hline Magnesium & Xylidyl Blue. Colorimetric & \\
\hline Chloride & Thiocyanate-Hg colorimetric & \\
\hline Phosphorus & Method with molibdenium & Emapol, Gdansk, Poland \\
\hline Iron & AMSFe1 Colorimetric & \multirow{2}{*}{$\begin{array}{l}\text { AMS International (AMS, UK } \\
\text { Ltd } 197\end{array}$} \\
\hline Total iron binding capacity & TIBC, AMSTIBC colorimetric & \\
\hline Sodium & Uranylthioglycolate Method & \multirow{2}{*}{$\begin{array}{lcr}\text { Egyptian } & \text { Co. } & \text { for } \\
\text { Biotechnology, } & \text { Obour } & \text { City } \\
\text { Industrial Area, } & \text { Cairo-Egypt }\end{array}$} \\
\hline Potassium & Tetraphenylborate Method & \\
\hline Zinc & 5-Br-PAPS method & \multirow{2}{*}{$\begin{array}{l}\text { Centronic GmbH (Wartenberg, } \\
\text { Germany) }\end{array}$} \\
\hline Copper & 3,5-Dibrom PAESA method & \\
\hline Aspartate aminotransferase & IFCC Enzymatic - UV method & \multirow{10}{*}{ Spinreact, GIRONA, Spain } \\
\hline Alanine aminotransferase & IFCC Enzymatic - UV method & \\
\hline Gamma glutamyl transferase & Carboxy substrate Kinetic method & \\
\hline Lactate dehydrogenase & DGKC Kinetic - UV method & \\
\hline Alkaline phosphatase & DGKC Kinetic optimized method & \\
\hline Creatine phosphokinase & NAC Kinetic-UV method & \\
\hline Blood urea nitrogen & Urease-GLDH Kinetic method & \\
\hline Creatinine & Jaffé Colorimetric-Kinetic method & \\
\hline Total bilirubin & DMSO - Colorimetric method & \\
\hline Direct bilirubin & DMSO - Colorimetric method & \\
\hline
\end{tabular}

Table 3: Reference values for serum proteins measured both by spectrophotometer and electrophoresis in late pregnant buffaloes

\begin{tabular}{|c|c|c|c|c|}
\hline & & Mean value & SD & Reference interval \\
\hline \multirow{4}{*}{ 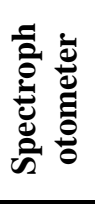 } & Total proteins $(\mathrm{g} / \mathrm{l})$ & 81.80 & 10.10 & $64.20-103.20$ \\
\hline & Albumin $(\mathrm{g} / \mathrm{l})$ & 35.60 & 6.30 & $22.40-46.80$ \\
\hline & Globulin $(\mathrm{g} / \mathrm{l})$ & 46.20 & 9.60 & $31.10-67.50$ \\
\hline & $\mathrm{A} / \mathrm{G}$ ratio & 0.81 & 0.24 & $0.38-1.40$ \\
\hline \multirow{5}{*}{ 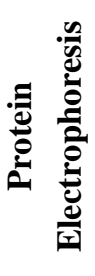 } & Albumin $(\mathrm{g} / \mathrm{l})$ & 42.60 & 8.00 & $27.70-60.50$ \\
\hline & Total Globulins $(\mathrm{g} / \mathrm{l})$ & 39.30 & 7.90 & $19.20-53.70$ \\
\hline & A-Globulins (g/l) & 11.00 & 2.50 & $7.10-16.40$ \\
\hline & B- Globulins (g/l) & 3.70 & 2.70 & $0.80-9.80$ \\
\hline & $\gamma$-Globulins (g/l) & 24.60 & 6.30 & $10.20-36.90$ \\
\hline
\end{tabular}

Reference interval $=2.5$ and 97.5 percentiles; reference interval $=$ interval between, and including, two reference limits. Reference intervals were calculated for each reference limit as recommended by PetitClerc and Solberg (1987). 
$\underline{\text { Assiut Vet. Med. J. Vol. } 59 \text { No. } 136 \text { January } 2013}$

Table 4: Reference values for serum enzyme activities in late pregnant buffaloes

\begin{tabular}{lccc}
\hline & Mean value & SD & Reference interval \\
\hline AST (U/l) & 57.51 & 16.61 & $24.21-93.40$ \\
\hline ALT (U/l) & 25.22 & 8.83 & $7.17-48.48$ \\
\hline GGT (U/l) & 12.03 & 4.90 & $2.75-21.86$ \\
\hline CK (U/l) & 90.68 & 77.50 & $11.44-292.92$ \\
\hline LDH (U/l) & 765.56 & 477.42 & $203.46-1636.54$ \\
\hline ALP (U/l) & 151.26 & 59.97 & $71.80-327.91$ \\
\hline
\end{tabular}

Reference interval $=2.5$ and 97.5 percentiles; reference interval $=$ interval between, and including, two reference limits. Reference intervals were calculated for each reference limit as recommended by PetitClerc and Solberg (1987).

Aspartate aminotransferase (AST), Alanine aminotransferase (ALT), Gamma glutamultransferase (GGT), Lactate dehydrogenase (LDH), alkaline phosphatase (ALP) and creatine phosphokinase (CK)

Table 5: Reference values for serum minerals and electrolytes in late pregnant buffaloes

\begin{tabular}{lcccc}
\hline & Unit & Mean value & SD & Reference interval \\
\hline \multirow{2}{*}{ Calcium } & $\mathrm{mmol} / \mathrm{l}$ & 2.72 & 0.43 & $1.86-3.46$ \\
\cline { 2 - 5 } Phosphorus & $\mathrm{mg} / \mathrm{dl}$ & 10.86 & 1.72 & $7.45-13.82$ \\
\hline \multirow{2}{*}{ Magnesium } & $\mathrm{mmol} / \mathrm{l}$ & 2.55 & 0.38 & $1.84-3.34$ \\
\cline { 2 - 5 } & $\mathrm{mg} / \mathrm{dl}$ & 7.91 & 1.17 & $5.71-10.35$ \\
\hline Sodium & $\mathrm{mmol} / \mathrm{l}$ & 2.55 & 0.38 & $1.84-3.34$ \\
\hline Chloride & $\mathrm{mg} / \mathrm{dl}$ & 3.09 & 0.46 & $2.20-3.93$ \\
\hline Potassium & $\mathrm{mmol} / 1$ & 144.74 & 8.35 & $129.96-160.46$ \\
\hline \multirow{2}{*}{ TIBC } & $\mathrm{mmol} / \mathrm{l}$ & 93.65 & 10.46 & $73.41-116.78$ \\
\hline \multirow{2}{*}{ Iron } & $\mathrm{mmol} / 1$ & 5.21 & 0.78 & $3.52-6.87$ \\
\hline \multirow{2}{*}{ UIBC } & $\mu \mathrm{mol} / \mathrm{l}$ & 37.88 & 7.54 & $24.03-57.15$ \\
\hline \multirow{2}{*}{ Copper } & $\mu \mathrm{g} / \mathrm{dl}$ & 211.64 & 42.12 & $134.27-319.26$ \\
\hline \multirow{2}{*}{ Zinc } & $\mu \mathrm{mol} / \mathrm{l}$ & 20.79 & 5.36 & $10.76-33.56$ \\
\hline & $\mu \mathrm{g} / \mathrm{dl}$ & 116.17 & 29.95 & $60.10-187.49$ \\
\hline & $\mu \mathrm{mol} / 1$ & 17.09 & 5.84 & $6.35-29.60$ \\
\cline { 2 - 5 } & $\mu \mathrm{g} / \mathrm{dl}$ & 95.47 & 32.61 & $35.45-165.36$ \\
\cline { 2 - 5 } & $\mu \mathrm{mol} / \mathrm{l}$ & 12.39 & 3.43 & $8.02-23.73$ \\
\cline { 2 - 5 } & $\mu \mathrm{g} / \mathrm{dl}$ & 78.91 & 21.86 & $51.08-151.15$ \\
\hline & $\mu \mathrm{mol} / \mathrm{l}$ & 12.41 & 3.06 & $7.99-20.03$ \\
\hline & $\mu \mathrm{g} / \mathrm{dl}$ & 81.11 & 20.02 & $52.27-130.90$ \\
\hline
\end{tabular}

Reference interval $=2.5$ and 97.5 percentiles; reference interval $=$ interval between, and including, two reference limits. Reference intervals were calculated as recommended by PetitClerc and Solberg (1987).

Total iron binding capacity (TIBC), Unsaturated iron binding capacity (UIBC). 
$\underline{\text { Assiut Vet. Med. J. Vol. } 59 \text { No. } 136 \text { January } 2013}$

Table 6: Reference values for biochemical serum variables in late pregnant buffaloes

\begin{tabular}{|c|c|c|c|c|}
\hline & Unit & Mean value & SD & Reference interval \\
\hline \multirow{2}{*}{ Total Cholesterol } & $\mathrm{mmol} / \mathrm{l}$ & 1.34 & 0.32 & $0.69-1.97$ \\
\hline & $\mathrm{mg} / \mathrm{dl}$ & 51.88 & 12.33 & $26.62-76.33$ \\
\hline \multirow{2}{*}{ Triglycerides } & $\mathrm{mmol} / \mathrm{l}$ & 0.24 & 0.15 & $0.12-0.67$ \\
\hline & $\mathrm{mg} / \mathrm{dl}$ & 21.22 & 13.81 & $10.36-59.36$ \\
\hline \multirow{2}{*}{ HDL-C } & $\mathrm{mmol} / 1$ & 0.54 & 0.23 & $0.20-1.18$ \\
\hline & $\mathrm{mg} / \mathrm{dl}$ & 20.73 & 8.78 & $7.78-45.37$ \\
\hline \multirow{2}{*}{ LDL-C } & $\mathrm{mmol} / 1$ & 0.68 & 0.29 & $0.14-1.30$ \\
\hline & $\mathrm{mg} / \mathrm{dl}$ & 26.14 & 11.22 & $5.29-50.17$ \\
\hline \multirow{2}{*}{ VLDL-C } & $\mathrm{mmol} / 1$ & 0.13 & 0.07 & $0.05-0.31$ \\
\hline & $\mathrm{mg} / \mathrm{dl}$ & 5.01 & 2.82 & $2.07-11.87$ \\
\hline \multirow{2}{*}{ Glucose } & $\mathrm{mmol} / \mathrm{l}$ & 2.84 & 1.07 & $1.24-5.41$ \\
\hline & $\mathrm{mg} / \mathrm{dl}$ & 51.22 & 19.36 & $22.33-97.49$ \\
\hline \multirow{2}{*}{ Total bilirubin } & $\mu \mathrm{mol} / \mathrm{l}$ & 7.01 & 2.91 & $2.56-14.54$ \\
\hline & $\mathrm{mg} / \mathrm{dl}$ & 0.41 & 0.17 & $0.15-0.85$ \\
\hline \multirow{2}{*}{ Direct bilirubin } & $\mu \mathrm{mol} / \mathrm{l}$ & 2.05 & 1.53 & $0.0-6.32$ \\
\hline & $\mathrm{mg} / \mathrm{dl}$ & 0.12 & 0.09 & $0.00-0.37$ \\
\hline \multirow{2}{*}{ Indirect Bilirubin } & $\mu \mathrm{mol} / 1$ & 4.95 & 2.39 & $0.51-10.94$ \\
\hline & $\mathrm{mg} / \mathrm{dl}$ & 0.29 & 0.14 & $0.03-0.64$ \\
\hline \multirow{2}{*}{ Creatinine } & $\mu \mathrm{mol} / 1$ & 152.93 & 30.94 & $94.58-222.77$ \\
\hline & $\mathrm{mg} / \mathrm{dl}$ & 1.73 & 0.35 & $1.07-2.52$ \\
\hline \multirow{2}{*}{ BUN } & $\mathrm{mmol} / \mathrm{l}$ & 12.51 & 4.81 & $4.74-22.89$ \\
\hline & $\mathrm{mg} / \mathrm{dl}$ & 34.19 & 13.47 & $13.28-64.11$ \\
\hline
\end{tabular}

Reference interval $=2.5$ and 97.5 percentiles; reference interval $=$ interval between, and including, two reference limits. Reference intervals were calculated as recommended by PetitClerc and Solberg (1987).

High density lipoprotein (HDL-C), low density lipoprotein (LDL-C), very low density lipoprotein (VLDL-C), blood urea nitrogen (BUN) 
$\underline{\text { Assiut Vet. Med. J. Vol. } 59 \text { No. } 136 \text { January } 2013}$

Table 7: Reference values for haematological variables in late pregnant buffaloes

\begin{tabular}{|c|c|c|c|}
\hline & Mean value & SD & Reference interval \\
\hline T. RBCs count $\left(\times 10^{12} / 1\right)$ & 6.53 & 0.84 & $5.24-8.40$ \\
\hline HGB $(g / 1)$ & 115.30 & 11.90 & $94.20-139.30$ \\
\hline $\mathrm{HCT}(\%)$ & 36.08 & 3.70 & $30.13-45.39$ \\
\hline $\operatorname{MCV}(f l)$ & 55.60 & 4.44 & $47.02-65.31$ \\
\hline $\mathrm{MCH}(\mathrm{pg})$ & 17.79 & 1.50 & $15.23-20.77$ \\
\hline $\mathrm{MCHC} \mathrm{g} / \mathrm{dl}$ & 32.02 & 1.05 & $30.32-33.98$ \\
\hline RDW $(\%)$ & 20.45 & 2.06 & $17.20-24.70$ \\
\hline $\mathrm{RDWa}(\mathrm{fl})$ & 39.66 & 3.78 & $32.43-47.58$ \\
\hline $\operatorname{PLT}\left(\mathrm{x} 10^{9} / \mathrm{l}\right)$ & 154.00 & 48.90 & $62.30-244.40$ \\
\hline MPV (fl) & 6.76 & 0.63 & $5.70-8.19$ \\
\hline PDW (\%) & 10.29 & 0.98 & $8.60-12.10$ \\
\hline $\mathrm{PCT}(\%)$ & 0.10 & 0.03 & $0.04-0.16$ \\
\hline LPCR $(\%)$ & 10.72 & 4.48 & $3.53-21.00$ \\
\hline T. WBC $\left(\times 10^{9} / 1\right)$ & 8.30 & 1.82 & $5.30-13.49$ \\
\hline Lymphocytes count $\left(\times 10^{9} / \mathrm{l}\right)$ & 4.72 & 1.53 & $2.39-8.16$ \\
\hline Neutrophiles count $\left(\times 10^{9} / 1\right)$ & 3.00 & 0.93 & $1.20-5.00$ \\
\hline Band cell count $\left(x 10^{9} / 1\right)$ & 0.07 & 0.06 & $0.00-0.29$ \\
\hline Eosinophils count $\left(\times 10^{9} / 1\right)$ & 0.28 & 0.20 & $0.00-0.72$ \\
\hline Monocytes count $\left(\times 10^{9} / 1\right)$ & 0.33 & 0.22 & $0.06-1.05$ \\
\hline Basophiles count $\left(\times 10^{9} / 1\right)$ & 0.00 & 0.00 & $0.00-0.00$ \\
\hline Lymphocytes (\%) & 55.80 & 10.40 & $34.0-76.7$ \\
\hline Neutrophiles (\%) & 36.10 & 9.60 & $16.50-57.00$ \\
\hline Band cell $(\%)$ & 0.80 & 1.00 & $0.00-3.00$ \\
\hline Eosinophils (\%) & 3.50 & 2.60 & $0.00-10.00$ \\
\hline Monocytes (\%) & 3.80 & 2.10 & $1.00-8.00$ \\
\hline Basophiles (\%) & 0.00 & 0.00 & $0.00-0.00$ \\
\hline
\end{tabular}

Reference interval $=2.5$ and 97.5 percentiles; reference interval $=$ interval between, and including, two reference limits. Reference intervals were calculated for each reference limit as recommended by PetitClerc and Solberg (1987).

Total red blood cells count (T.RBCs), hemoglobin concentration (HGB), red blood cells distribution width (RDW), red blood cells distribution width absolute (RDWa), hematocrit (HCT), main corpuscular volume (MCV), mean corpuscular hemoglobin $(\mathrm{MCH})$, mean corpuscular hemoglobin concentration (MCHC), platelets count (PLT), mean platelets volume (MPV), platelets distribution width (PDW), large platelets concentration ratio (LPCR), plateletcrit (PCT), total white blood cells count (T.WBCs),

\section{DISCUSSION}

The International Federation of Clinical Chemistry sets out clear guidelines for the production of reference values and limits. They recommended at least 120 animals being used for establishing the reference values (Grasbeck et al., 1979). This study used and carefully selected a relatively large reference population of 125 animals, which is higher than the number of animals recommended for establishing the reference values (Lumsden and Mullen, 1978; Grasbeck et al., 1979; Lumsden and Jacobs, 1989; Farver, 1997; Solberg, 1999 and Geffré et al., 2009). Buffaloes (Bubalus bubalis) subject to 
study were selected from farms to ensure that they received periodical clinical examination, reared approximately under the same management system and their productive and reproductive status were regularly checked and recorded. Also, the physiological condition of the reference sample population was defined and reference intervals were calculated as 0.025 and 0.975 fractiles with $90 \%$ confidence intervals for the limits. It is well known that there are profound physiological changes in hematological and serum biochemical constituents in late pregnant buffaloes. These changes are not necessarily indicative of disease but reflect physiological demands. Pregnant buffaloes included in the present study were selected precisely based on the established basic slection criteria stated in Table 1.

In the present study, mean values and reference intervals for body temperature were $38.47 \pm 0.33{ }^{\circ} \mathrm{C}$ and $37.80-39.30 \circ \mathrm{C}$ respectively, which agreed with FAO (1994). The results also were in-accordance with values reported by Radostits et al. (2006).

Mean values for serum total proteins reported in the present study was $81.8 \pm 10.1 \mathrm{~g} / \mathrm{l}$ (Table 3 ), which is higher than normal serum protein levels reported in none pregnant buffaloes $(64.5 \pm 4.0 \mathrm{~g} / \mathrm{l})$ by Abd Ellah (2011). Quayam et al. (1990) reported that serum total proteins at 60 days prepartum was ranged from 91.20-93.70 $\mathrm{g} / \mathrm{l}$, which is lower than the upper limit for serum protein (64.20-103.20 g/l) established in the present study. Results of this study revealed that serum albumin measured by electrophoresis was higher than that determined by colorimetric methods. Furthermore, calculated globulins by colorimetric method were higher than globulins measured by electrophoresis (Table 3). The largest proportion of globulins was in the form of $\gamma$-globulins $(24.60 \pm 6.30$ $\mathrm{g} / \mathrm{l})$, followed by $\alpha$-globulins $(11.00 \pm 2.50 \mathrm{~g} / \mathrm{l})$ and then $\beta$-globulins $(3.70 \pm 2.70 \mathrm{~g} / \mathrm{l})$, the same was reported by Saleh et al. (2008). Mean value for serum globulins from the present study $(46.20 \pm 9.60$ $\mathrm{g} / \mathrm{l})$ was slightly lower than value reported by Ali et al. (2011), who stated that globulins level in late pregnant buffaloes was $52.20 \pm 6.50 \mathrm{~g} / \mathrm{l}$. As shown in Table 3, reference intervals for serum total proteins, albumin and globulins were 64.20-103.20, 22.4046.80 and $31.10-67.50 \mathrm{~g} / 1$, respectively, which were higher than reported $(58.2-79.7,27.4-38.1$ and 28.5$46.3 \mathrm{~g} / \mathrm{l}$, respectively) in none pregnant buffaloes by Saleh et al. (2008). Also, the results of this study for serum proteins and fractions were higher than levels reported by other studies on non-lactating buffaloes (Abd Ellah, 2011). Differences between the current and previous studies may be attributed to variations in the physiological and/or climatic conditions. High serum proteins levels reported in the current study may be attributed to elevation of serum globulins and represent immunological response of the late pregnant buffaloes to provide the newly born calf with sufficient globulins in colostrum. In cows, total serum protein and globulin begin to increase two months before term, reach a maximum a month before term and then rapidly decline towards term, where the immunoglobulin rapidly leaves the plasma during the last month of gestation, when colostrum is being formed in the mammary glands (Larson and Kendall, 1957).

The present study (Table 4) revealed that, mean value for serum AST was 57.51 \pm 16.61 , which is higher than mean value for serum AST $(44.25 \pm 3.77$ U/1) reported by Serdaru et al. (2011), and lower than mean value $(72.8 \pm 7.2 \mathrm{IU} / \mathrm{l})$ reported by Ali et al. (2011) in pregnant buffaloes. Ghanem and El-Deeb (2010) reported that serum AST level in adult buffaloes was $70.6 \pm 4.16 \mathrm{U} / \mathrm{l}$, which is higher than its serum level at the present study. Serum ALT from the investigated buffaloes $(25.2 \pm 8.8 \mathrm{U} / \mathrm{l})$ was higher than level of $21.86 \pm 5.34$ reported by Abd Ellah (2011) in none pregnant buffaloes.. Mean value for serum GGT level $(12.03 \pm 4.9 \mathrm{U} / \mathrm{I})$ in the investigated buffaloes was higher than mean values of $7.21 \mathrm{U} / \mathrm{I}$ reported by Ghanem and El-Deeb (2010). In healthy adult buffaloes, it was reported that serum $\mathrm{LDH}$ ranged from 1500.41 to $1603.17 \mathrm{U} / 1$ (Grasso et al., 2004), which seems lower than serum LDH (203.46$1636.54 \mathrm{U} / \mathrm{l}$ ) obtained from this study. Normal range for serum ALP was reported to be ranged from 370.11 to $433.12 \mathrm{U} / \mathrm{l}$ in adult buffaloes under different housing conditions (Grasso et al., 2004). Differences in the serum ALP mean values of buffaloes at various distances from partum, increasing in the advanced phases of pregnancy and decreasing before parturition had been reported (Pizzuti and Salvatori, 1993), during which its level was ranged from 159 to $228 \mathrm{U} / \mathrm{l}$. The upper limit for the reference interval of serum ALP obtained from the present study was higher than result reported by Pizzuti and Salvatori (1993) and lower than findings by Grasso et al. (2004). Serdaru et al. (2011) reported that serum ALP level was $147 \pm 24.71 \mathrm{U} / \mathrm{l}$, which agree with mean value $(151.26 \pm 59.97 \mathrm{U} / \mathrm{l})$ obtained from this study. Mean serum value for serum Ck (90.68 U/l) from the studied animals was higher than values reported in pregnant buffaloes by Ali et al. (2011). The variation in serum enzymes levels may be attributed to variation in age of the animals, stage of pregnancy and/or breed of buffaloes.

Minerals are essential nutrients bearing a significant role in the animal reproduction, because their excess or deficiency produces detrimental effect on the performance of livestock. Trace elements including copper, zinc and iron, and certain macro-elements like calcium, magnesium and phosphorus, and 
electrolytes like sodium and chloride have been found to be very essential for normal livestock growth (Underwood, 1981). Reference intervals for minerals established in the present study reflected their serum levels during the late pregnancy in buffaloes (Table 5). Pathak et al. (1987) reported that mean value for serum calcium, phosphorus and magnesium in late pregnant buffaloes were 10.90 $\mathrm{mg} / \mathrm{dl}, 7.23 \mathrm{mg} / \mathrm{dl}$ and $3.37 \mathrm{mg} / \mathrm{dl}$ respectively, which were agreed with mean serum values for calcium $(10.86 \pm 1.72 \mathrm{mg} / \mathrm{dl})$ phosphorus $(7.91 \pm 1.17 \mathrm{mg} / \mathrm{dl})$ and magnesium $(3.09 \pm 0.46 \mathrm{mg} / \mathrm{dl})$ of the present study (Table 5). Furthermore, serum calcium and phosphorus from the present study was higher than values for calcium $(9.85 \pm 0.63 \mathrm{mg} / \mathrm{dl})$ and phosphorus $(4.33 \pm 0.55 \mathrm{mg} / \mathrm{dl})$ recorded in late pregnant buffaloes by Hanif et al. (1984). Also, Hanif et al. (1984) found that plasma copper and zinc levels were $83.00 \pm 4.00 \mu \mathrm{g} / \mathrm{dl}$ and $72.00 \pm 6.00 \mu \mathrm{g} / \mathrm{dl}$ respectively, which were slightly different from serum copper $(78.91 \pm 21.86 \mu \mathrm{g} / \mathrm{dl})$ and zinc $(81.1 \pm 20.0 \mu \mathrm{g} / \mathrm{dl})$ from the present study. Another study done by Kumar et al. (2001) on pregnant Murrah buffaloes, which revealed that the mean values for serum calcium, phosphorus, magnesium and iron concentrations were $\quad 11.83 \pm 1.17 \mathrm{mg} / \mathrm{dl}, \quad 4.84 \pm 1.44 \mathrm{mg} / \mathrm{dl}$, $1.88 \pm 0.26 \mathrm{mg} / \mathrm{dl}$ and $93.80 \pm 10.36 \mu \mathrm{g} / \mathrm{dl}$, respectively. Comparing results reported by Kumar et al. (2001) with results presented in Table 5, revealed that serum levels of phosphorus, magnesium and iron were lower and serum calcium was higher than values reported in the present study. Mean serum potassium $(5.21 \pm 0.78 \mathrm{mmol} / \mathrm{l})$ presented in table 5 , was higher than mean value $(4.53 \mathrm{mmol} / \mathrm{l})$ reported by Hussain et al. (2001) in pregnant buffaloes. It was concluded that mean serum sodium levels in pregnant buffaloes was $145.71 \mathrm{mmol} / \mathrm{l}$, which was slightly different from the mean serum sodium (144.74 mmol/l) obtained from the present study. The slight differences in the mean values for serum minerals reported in the present study and previous studies may be attributed to breed, nutritional and climatic condition differences.

Large species differences in lipoproteins profiles and the percentage of total cholesterol and triglycerides carried by each lipoprotein class were recorded in different animals. Whereas in human and pigs, the majority of cholesterol is transported as LDL-C, in cattle, cholesterol is equally divided between LDL-C and HDL-C, while in sheep and horses, the majority of cholesterol circulates as HDL-C (Latimer et al., 2003). Mean values of serum total cholesterol $(51.8 \pm 12.3 \mathrm{mg} / \mathrm{dl})$, HDL-C $(20.7 \pm 8.9 \mathrm{mg} / \mathrm{dl})$, LDL-C $(26.1 \pm 11.2 \mathrm{mg} / \mathrm{dl})$ and VLDL-C $(5.0 \pm 2.8 \mathrm{mg} / \mathrm{dl})$ established in the present study were lower than findings of previous studies on none pregnant buffaloes (Abd Ellah, 2011 and Tajik and Nazifi,
2011). The present study revealed that serum LDL-C levels were slightly higher than serum HDL-C during the late pregnancy in buffaloes (Table 6), which disagreed with that reported by Tajik and Nazifi (2011) in serum of none pregnant Iranian water buffaloes. The increased serum LDL-C in late pregnant buffaloes may be attributed to the increased demand of cholesterol for synthesis of steroid hormones (Grummer and Carroll, 1988). According to the results of this study, mean value for serum triglycerides during late pregnancy was $0.24 \pm 0.15$ $\mathrm{mmol} / \mathrm{l}$, which was higher than estimated values during lactation $(0.1 \mathrm{mmol} / \mathrm{l})$ (Grasso et al., 2004). However, mean value for triglycerides obtained from the present study was lower than that reported by Ghanem and El-Deeb (2010), who reported that serum triglycerides was of $0.34 \mathrm{mmol} / \mathrm{l}$ in Egyptian water buffaloes. In a previous study, mean serum glucose were $40.46 \mathrm{mg} / \mathrm{dl}$ as reported by Majeed et al. (1990), which is lower than mean glucose level from the present study. This may be attributed to the difference in physiological conditions.

At present, the complete blood cell count can be performed using an automated hematology analyzer, which can increase the throughput of the test. Recently, new indices related to erythrocytes (RDW, RDWa, and platelet (PCT, MPV, PDW, LPCR) have been provided by hematologic analyzers (Lombarts et al., 1986). The current study is the first one that provided a reference values for these new indices in late pregnant buffaloes. Reference limits of hematological analytes developed in the present study (Table 7), were slightly differed from those developed by Ciaramella et al. (2005) in primipara buffaloes. Mean hematological values from this study were lower than RBCs count $\left(6.9 \pm 0.7 \times 10^{12} / 1\right)$, $\mathrm{Hgb}(140 \pm 9.8 \mathrm{~g} / \mathrm{l}), \mathrm{MCH}(19.8 \pm 2.1 \mathrm{pg})$ and $\mathrm{MCHC}$ $(40 \pm 1.6 \mathrm{~g} / \mathrm{dl})$ and higher than HCT $(33 \pm 0.1 \%)$ and MCV (49.6 $\pm 5.4 \mathrm{fl})$ reported by Ciaramella et al. (2005). Total WBCs count $\left(8.3 \pm 1.8 \times 10^{9} / 1\right)$ from the present study was lower than WBCs count $\left(8.02 \pm 0.9 \times 10^{9} / 1\right)$ reported by Ciaramella et al. (2005). Also, differential leucocytes counts recorded by Ciaramella et al. (2005) were slightly different from that obtained from the current study. Reference intervals for platelets count $\left(62-244 \times 10^{9} / 1\right)$ and MPV (5.7-8.19fl) from the present study were lower than previously reported normal ranges in lactating buffaloes (Fagiolo et al., 2004), which were ranged from $201-251.8 \times 10^{9} / 1$ and $8.8-9.7 \mathrm{fl}$ for PLT count and MPV respectively. Differences may be attributed to stage of pregnancy, climatic conditions or breed of buffaloes. 


\section{CONCLUSION}

The present study represents the first that estimated reference values for the serum biochemical and hematological constituents in late pregnant buffaloes. Reference values for serum biochemical and hematological variables for buffaloes during the late pregnancy were established in the present study. The established reference values will be a useful guide for interpreting serum biochemical and hematologic data in late pregnant buffaloes, especially those live under the Egyptian environment.

\section{ACKNOWLEDGMENTS}

This work was supported by Basic and Applied Research Project (ID: 2947) from Science and Technology Development Fund (STDF), Ministry of Scientific Research, Egypt. The authors greatly appreciate the help of the members at the Department of Animal Health Care at the Veterinary Directorate for facilitating the examination of animals and collection of samples from buffalo's farms.

\section{REFERENCES}

Abd Ellah, M.R. (2011): Serum Metabolic Profile of Idiopathic Emaciated Buffaloes, Journal of Animal and Veterinary Advances 10 (18): 2456-2458.

Ali, A.; Derar, R.; Hussein, H.A.; Abd Ellah, M.R. and Abdel-Razek, A.Kh. (2011): Clinical, hematological, and biochemical findings of uterine torsion in buffaloes (Bubalus bubalis). Animal Reproduction Science 126: 168-172.

Anderson, T.W. and Darling, D.A. (1954): A Test of Goodness-of-Fit. Journal of the American Statistical Association 49: 765-769.

Bailey, S.M.; Sarmandal, P. and Grant, J.M. (1989): A comparison of three methods of assessing interobserver variation applied to measurement of the symphysis-fundal height. British Journal of Obstetrics and Gynecology 96: 1266-1271.

Ciaramella, P.; Corona, M.; Ambrosio, R.; Consalvo, F. and Persechino, A. (2005): Haematological profile on non-lactating Mediterranean buffaloes (Bubalus bubalis) ranging in age from 24 months to 14 years. Research in Veterinary Science. 79 (1): 77-80.

Cockril, W.R. (1980): The ascendant water buffalo key domestic animal. World Animal Review 33: 2-13.

Coles, E.H. (1986): Veterinary Clinical Pathology, 4th Ed., Saunders Comp. Philadelphia, London, Toronto.
Fagiolo, A.; Lai, O.; Alfieri, L.; Nardon, A. and Cavallina, R. (2004): Environmental factors and different managements that influence metabolic, endocrine and immuno responses in water buffalo during lactation. Proc. Seventh World Buffalo Congress, Manila, Philippines. pp. 24-26.

FAO (1994): A manual for the primary animal health care worker. FAO Animal Health Manual Food and Agriculture Organization of the United Nations, Rome.

Farver, T.B. (1997): Concepts of normality in clinical biochemistry. In: Kaneko JJ, Harvey JW, Bruss ML, editors. Clinical Biochemistry of Domestic Animals. 5th ed. San Diego: Academic Press. pp. 1-19.

Geffré, A.; Concordet, D.; Braun, J.P. and Trumel, C. (2011): Reference Value Advisor: A new freeware set of macroinstructions to calculate reference intervals with Microsoft Excel. Veterinary Clinical Pathology 40: 107-112.

Geffré, A.; Kristen, F.; Kendal, H.; Didier, C.; Catherine, T. and Jean-Pierre, B. (2009): Reference values: a review. Veterinary Clinical Pathology 38: 288-298.

GOVS, (2005): Technical veterinary report. General Organization of Veterinary Service, Cairo, Egypt.

Ghanem, M.M. and El-Deeb, W.M. (2010): Lecithin cholesterol acyltransferase (LCAT) activity as a predictor for ketosis and parturient haemoglobinuria in Egyptian water buffaloes. Research in Veterinary Science 88: 20-25.

Grasbeck, R.; Siest, G.; Wilding, P.; Williams, G.Z. and Whitehead, T.P. (1979): Provisional recommendation on the theory of reference values. Part 1. The concept of reference values. Clinical Chemistry 25: 1506-1508.

Grasso, F.; Terzano, G.M.; De Rosal, G.; Tripaldi, C. and Napolitano, F. (2004): Influence of housing conditions and calving distance on blood metabolites in water buffalo cows. Ital. J. Anim. Sci. 3: 275-282.

Grummer, R.R. and Carroll, D.J. (1988): A review of lipoprotein cholesterol metabolism: importance to ovarian function. J. Anim. Sci. 66: 3160-3173.

Hanif, M.; Ali, C.S.; Samad, H.A. and Hanjra, S.H. (1984): Influence of pregnancy stress on blood mineral profile in the buffalo. Pakistan Veterinary Journal 4: 165-168.

Hussain, S.; Saeed, M.A. and Bashir, J.N. (2001): Serum electrolytes in buffaloes during late pregnancy parturition and postpartum periods. Pakistan Vet. J. 21: 175-179.

Kenneth, D.M. (2001): Clinical Laboratory Medicine. 2nd Ed., Lippincott Williams and Wilkins, p. 313. 
Klinkhoff, A.V.; BellamyBombardier, N.C.; Carette, $S$. and Chalmers, A. (1988): An experiment in reducing interobserver variability of the examination for joint tenderness. The Journal of Rheumatology 15: 492-494.

Kumar, R.; Sharma, I.J.; Rao, M.L.V. and Quadri, M.A. (2001): Status of haemogram, plasma proteins, minerals and electrolytes during pregnancy, anorexia and sub- clinical ketosis in cows and buffaloes. Indian Journal of Animal Science 71 (2): 118-121.

Larson, B.L. and Kendall, K.A. (1957): Changes m specific blood serum protein levels associated with parturition in the bovine. J. Dairy Sci. 40: 659 .

Latimer, K.S.; Prasse, K.W. and Mahaffey, E.A. (2003): Proteins, Lipids, and Carbohydrates. In: Duncan and Prasse's Veterinary Laboratory Medicine: Clinical Pathology, $4^{\text {th }}$ ed. Ames, Iowa State University Press, pp. 162-192.

Lombarts, A.J.; Koevoet, A.L. and Leijnse, B. (1986): Basic principles and problems of haemocytometry. Ann. Clin. Biochem. 23: 390.

Lumsden, J.H. and Mullen, K. (1978): On establishing reference values. Can. J. Comp. Med. 42: 293-301.

Lumsden, J.H. and Jacobs, R.M. (1989): Clinical chemistry. in-clinic analysis, quality control, reference values, and system selection. Vet. Clin. North Am Small Anim. Prac. 19: 875897.

Majeed, M.A.; Iqbal, J. and Chaudhry, M.N. (1990): Blood chemistry of clinical metritis in NiliRavi buffaloes of two age-groups and at two stages of lactation. Pakistan Vet. J. 10(2): 5559.

Pathak, M.M. and Janakiraman, K. (1987): Blood serum calcium, inorganic phosphorus and magnesium at different stages of pregnancy in Surti buffaloes. Indian Journal of Animal Science 57: 398-402.

Pattinson, R.C. and Theron, G.B. (1989): Interobserver variation in symphysis-fundus measurements. A plea for individualised antenatal care. South African Medical Journal 76: 621-622.

PetitClerc, C. and Solberg, H.E. (1987): Approved recommendation on the theory of reference values. Part 2. Selection of individuals for the production of reference values. Clinical Chemistry Acta 170: S1-S11.

Pizzuti, G.P. and Salvatori, G.C. (1993): Some blood parameters of water buffalo in different physiological conditions. Boll. Soc. Italian. Sper. 69: 649-654.
Quayam, S.A.; Devanathan, T.G. and Pattabiraman, S.R. (1990): Serum total protein and blood glucose levels during pre-, peri- and postpartum Murrah buffaloes. Indian Journal of Animal Sciences 60: 140-142.

Radostits, O.M.; Gay, C.C.; Hinchcliff, K.W. and Constable, P.D. (2006): Veterinary Medicine: A Text Book of the Diseases of Cattle, Sheep, Pigs, Goats and Horses. $10^{\text {th }}$ Edition, Bailliere Tindall London Philadelphia Sydney Tokyo Toronto. pp. 12-13.

Reed, A.H.; Henry, R.J. and Mason, W.B. (1971): Influence of Statistical Method Used on the Resulting Estimate of Normal Range. Clinical Chemistry 17: 275-284.

Saleh, M.A.; Rateb, H.Z. and Misk, N.A. (2008): Comparison of blood serum proteins in water buffaloes with traumatic reticuloperitonitis and sequellae. Research in Veterinary Science 85: 208-213.

Serdaru, M.; Nicolae, I.; Enculescu, M.; Bota, A. and Bolocan, E. (2011): Seasonal Variations of some Hematological and Biochemical Parameters of the Carpathian Romanian Buffaloes. I. The Winter Period Animal Science and Biotechnologies 44 (1): 94-98

Solberg, H.E. (1999): Establishment and use of reference values. In: Burtis CA, Ashwood ER, editors. Tietz Textbook of Clinical Chemistry. 3rd ed. New Dehli, India: Harcourt Brace, Asia Sauders, pp. 336-354.

Solberg, H.E. (1987): Provisional recommendation on the theory of reference values. Part 5: statistical treatment of selected reference values. Determination of reference limits. Journal of Clinical Chemistry and Clinical Biochemistry 25: 645-656.

Soulsby, E.J.L. (1982): Helminths, Arthropods and Protozoa of Domesticated Animals. $7^{\text {th }}$ ed. ELBS, London. p. 809.

Tajik, J. and Nazifi, S. (2011): Serum Concentrations of Lipids and Lipoproteins and Their Correlations together and with Thyroid Hormones in Iranian Water Buffalo (Bulbalus bulbalis). Asian Journal of Animal Sciences 5 (3): 196-201.

Theodossi, A.; Knill-Jones, R.P.; Skene, A.; Lindberg, G.; Bjerregaard, B.; HolstChristensen, J. and Williams, R. (1981): Interobserver variation of symptoms and signs in jaundice. Liver 1: 21-32.

Underwood, E.J. (1981): The Mineral Nutrition of Livestock. Commonwealth Agricultural Bureau. London, UK.

Webster, C.C. and Wilson, P.N. (1980): Agriculture in the Tropics. second ed. Longman ELBS), London, UK. pp. 390-400. 
$\underline{\text { Assiut Vet. Med. J. Vol. } 59 \text { No. } 136 \text { January } 2013}$

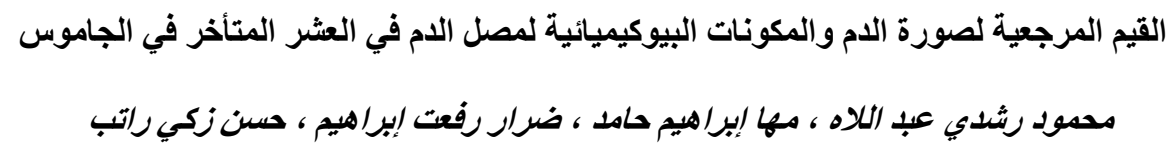

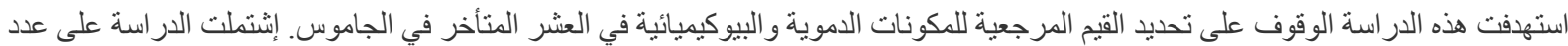

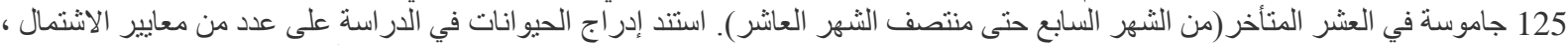

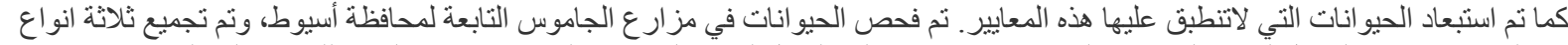

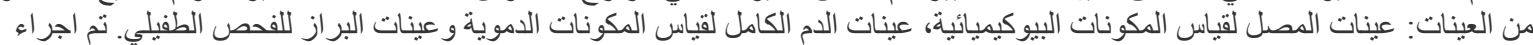

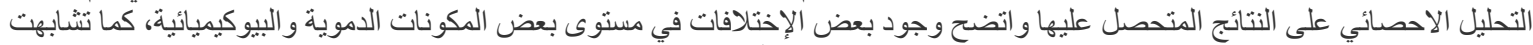

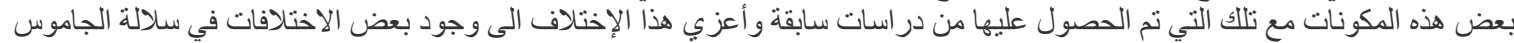

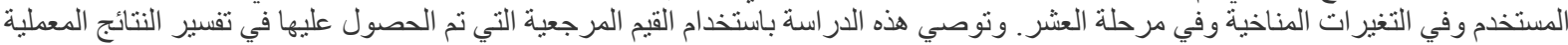
للمكونات البيوكيميائية والدموية للجاموس في في العشر الثنة المتاخر. الكلمات الدالة: الدصل، القبم الدرجعبة، الجاموس، العثر 